\title{
Buffetrille Katia (ed.), Revisiting Rituals in a Changing
} Tibetan World

Leiden, Brill, 2012, vii-386 p., ISBN 9789004232174

Nicolas Sihlé

\section{(2) OpenEdition}

\section{Journals}

Édition électronique

URL : https://journals.openedition.org/emscat/2682

DOI : 10.4000/emscat.2682

ISSN : 2101-0013

Éditeur

Centre d'Etudes Mongoles \& Sibériennes / École Pratique des Hautes Études

Référence électronique

Nicolas Sihlé, "Buffetrille Katia (ed.), Revisiting Rituals in a Changing Tibetan World », Études mongoles et sibériennes, centrasiatiques et tibétaines [En ligne], 46 | 2015, mis en ligne le 10 septembre 2015, consulté le 13 juillet 2021. URL : http://journals.openedition.org/emscat/2682 ; DOI : https://doi.org/ $10.4000 /$ emscat.2682

Ce document a été généré automatiquement le 13 juillet 2021.

(c) Tous droits réservés 


\title{
Buffetrille Katia (ed.), Revisiting Rituals in a Changing Tibetan World
}

\author{
Leiden, Brill, 2012, vii-386 p., ISBN 9789004232174
}

Nicolas Sihlé

\section{RÉFÉRENCE}

Buffetrille Katia (ed.), Revisiting Rituals in a Changing Tibetan World, Leiden, Brill, 2012

1 Revisiting Rituals in a Changing Tibetan World is a very welcome, carefully produced addition to Brill's by now well-known "Tibetan library" series. It contains the proceedings of a conference on the contemporary transformation of rituals in the Tibetan cultural area, held at the Collège de France in November 2007. The volume is thematically focused, but not rigidly so, allowing for explorations of neighbouring domains, such as Buddhist contexts marked by the influence of Tibetan Buddhism, or topics going somewhat beyond a central focus on ritual per se. One might have imagined a more thematic organisation of chapters, focusing for instance on issues of change and innovation in religious rituals (Barnett, Buffetrille, Even, Helffer, von Rospatt), similar issues with regard to rites of passage and other social or socio-political rituals (Dodin, Jagou, Schneider), and questions of ritualization (Diemberger, Pirie). The somewhat simpler and more straightforward structure chosen by editor K. Buffetrille seems to be rather geographically inspired, moving from Tibetan locations within the confines of the present-day People's Republic of China to Himalayan and/or exile contexts, and finally to cases in which the Tibetan component is less dominant, as the focus shifts to neighbouring cultural contexts (Newar or Mongolian), in which the influence of Tibetan Buddhism and its clergy is only one of the factors of religious change. Finally, a chapter by R. Barnett, which brings us back to Tibetan contexts, is with its 102 pages almost a small book-length study in itself, and is placed at the end of the volume. 
2 The short introduction (Chapter 1) by the editor provides some historical context for the inclusion of less Tibet-centred materials, in the form of a reminder of the close historical relationships, in particular in the religious sphere, between Tibet and its Nepalese and Mongolian neighbours. It then concludes with a summary of each of the volume's contributions. As in many volumes of conference proceedings, there is no attempt here to draw links a posteriori between the papers - which in effect are rather diverse in topic and orientation. This being so, the present review will have to limit itself to outlining each individual chapter very briefly (in effect, much of their merits will have to go unaddressed, for lack of space), and to offering only a few comments.

3 Chapter 2, "Holy Books as Ritual Objects and Vessels of Teachings in the Era of the Further Spread of the Doctrine", by H. Diemberger, gathers a variety of observations on holy books and their place in Tibetan religiosity, far beyond the contemporary period alone (and at some remove from the theme of ritual per se). This chapter is one of the very few that adopts an explicit analytical perspective. Following Gell's work on the agency of artworks (and other objects), the author suggests that we may consider Tibetan religious books as endowed with agency "in an indirect sense", as “"extensions' of persons as part of their 'distributed personhood"' (p.11). The author provides a whole range of semantic and cultural data, showing that books can be interpreted as sometimes being treated like high-status persons - an intriguing analytical suggestion indeed. In one of the later sections, the author suggests that "books seem to deploy the power to mobilise the people around them, and get people to relate to one another and build networks to rescue, preserve, re-discover and also assess" the surviving books (p. 24). In this particular case, one may wonder whether there is any clear empirical justification or analytical gain in switching from a vocabulary of collective values and human actors rallying in defence of the Buddhist dharma to a vocabulary of the agency of books. The author's general, stimulating suggestion however definitely merits our attention and further examination.

4 In the next chapter, "The Use of the Ritual Drawing of Lots for the Selection of the 11th Panchen Lama", F. Jagou examines the procedure of "drawing lots from the golden urn", which was instituted in 1792 by the Qing court for the recognition of high reincarnate Buddhist masters in Tibet, including in particular the Dalai Lamas and Panchen Lamas. The analysis demonstrates the court's concerns about fighting corruption and nepotism in such matters, both in Mongolia and in Tibet. The author then examines the way in which this procedure has come to be invoked by PRC state authorities at the time of the disputed recognition of the 11th Panchen Lama in 1995. PRC state authorities' claims to an historical precedent in this matter are examined primarily from the perspective of, one could say, jurisprudence, by considering elements of continuity as well as departures from traditional politico-religious patterns. The author refrains from providing an explicit conclusion, but the analysis points clearly enough to a lack of legitimacy of the PRC authorities' claims in this matter, given the massive political reordering since the Qing era. Beyond this critical scrutiny of the PRC's official justifications, a few words address what could be said, in effect, to underlie the claims of the PRC state, namely the political instrumentalisation of a politico-religious ritual from a past era (a mode of analysis adopted more centrally by Sperling 2012). ${ }^{1}$

5 T. Dodin's chapter, "Transformed Rituals? Some Reflections on the Paradigm of the Transformation of Rituals in the Tibetan Context", is a careful, sustained, and on the 
whole convincingly argued critique of the notion that we have seen in certain political or politico-religious events in Tibet over recent decades, a "transformation" of religious rituals into political ones. Dodin refers here to Schwartz's 1994 book Circles [sic, for Circle] of Protest, in which the author argues that the momentous 1987 demonstrations in Lhasa, in which groups of demonstrators repeatedly (although not exclusively) walked around the Barkor (a circular route surrounding the Jokhang chapel, the sacred heart of Tibetan Buddhism), were a transformation of religious circumambulations. More recent public events with a strong political significance are also discussed by Dodin, who concludes that none of them qualify as "transformations" of religious rituals. It is not clear, however, whether anyone has actually made that claim and whether the term "paradigm" in the chapter's title might perhaps be regarded as slightly too strong.

In Chapter 5, "Legal Dramas on the Amdo Grasslands: Abolition, Transformation or Survival ?", F. Pirie examines both traditional and more modern forms of mediation processes in feuds among pastoralists in Tibet's north-eastern province, Amdo. Starting from relatively standard working definitions of "secular ritual", Pirie offers a sophisticated, rigorous examination of the extent to which the notion of "ritual" might be considered to apply to these mediation procedures, resulting in the conclusion that there is actually little reason to do so. The author notes that "weakly-ritualised "performances"' (p. 93) might be more accurate. In effect, the discussion could perhaps have escaped its slightly unhelpful binary character - "ritual" or not "ritual" - by shifting the vocabulary to that of ritualisation. However, even within that more rigid framework, Pirie's discussion is still nuanced. Examples and insights from legal or ritual anthropology, based on work carried out in other cultural contexts, are also brought in to suggest contrasts, in order to construct the argument; the result proves sound and convincing.

7 N. Schneider's chapter, "The Ordination of Dge slong $m a$ : a Challenge to Ritual Prescriptions ?", provides a narrative account of the recent debates, primarily within the Tibetan high clergy in exile, surrounding the issue of introducing full monastic ordination for women in Tibetan Buddhism, and of the obstacles that have prevented these debates from moving ahead, or even taking place at all. It summarises the arguments of both proponents and opponents of the project. What also clearly emerges is the politics of the debate. The Dalai Lama and a few other prominent figures have expressed support, but the required quorum for tackling the difficult question amounting to a possible transformation of the tradition has never been reached, as many members of the high clergy make the strategic choice of not responding. The most active driving force behind the debate seems to be Western feminist practitioners; nuns in Tibet itself seem to not even discuss the issue (p. 118), and the author herself adopts a very neutral voice in this regard.

8 In Chapter 7, "Preservation and Transformations of Liturgical Traditions in Exile: the Case of Zhe chen Monastery in Bodnath (Nepal)", M. Helffer summarizes the establishment of new Tibetan monastic institutions in exile (focusing on the Zhechen nyingmapa monastery), the efforts made to preserve the continuity of ritual traditions, and the content of Zhechen's annual ritual cycle. Some recent changes or innovations are noted, in particular the development of the performance of certain ritual dances in non-religious contexts, especially for Western audiences. The author identifies a variety of forces at play in these situations : figures of religious authority (e.g. Dilgo 
Khyentse Rinpoche), whose presence is marked by a cyclical character as they appear through a principle of succession by reincarnation; powerful patrons, such as the Bhutanese royal family; influential cultural brokers like the French monk Matthieu Ricard; economic needs (with world tours as a means of securing income for the monastery); and global forces, such as the benefits to be obtained through the inclusion of the monastery's masked dances on UNESCO's Intangible Heritage list.

K. Buffetrille's chapter, "Low Tricks and High Stakes Surrounding a Holy Place in Eastern Nepal: the Halesi-Māratika Caves", analyses recent developments at a disputed, multi-ethnic Hindu-Buddhist sacred site in Nepal. The fascinating politics that have played out here (and that the author analyses basing herself on rich data gathered over a period of fifteen years) are at the centre of the chapter. These politics are both very local and a reflection of larger forces : development plans of the Nepalese state, ethnic revival in Nepal (with substantial Sherpa involvement), Maoist interference during the People's War, but also the current vitality of Tibetan Buddhism, with its post-exile search for new holy places that borders on colonisation (p. 199). The part of the chapter devoted more specifically to collective rituals carried out at this sacred site (pp. 192-194) provides also a brief tantalizing insight into the participation of this place and of its caretakers in a larger, recent movement which has seen major Tibetan religious gatherings being held, in particular at special holy sites, for reasons, such as "world peace", that sometimes show a clear modern Western influence. (This development has started to be mentioned in a variety of works and would greatly deserve sustained ethnographic, comparative and theoretical attention.)

With A. von Rospatt's chapter, "Past Continuity and Recent Changes in the Ritual Practice of Newar Buddhism : Reflections on the Impact of Tibetan Buddhism and the Advent of Modernity", we move to the first of two contributions that examine changes in neighbouring, related cultural contexts. This chapter provides a timely, highly synthetic (and, to this reader, very welcome) overview of four major areas of recent change in Newar Buddhism, in a context of strong pressures deriving from a variety of factors: a small but very critical modernist Theravāda movement, the increasing presence (if not encroachment on sacred sites) of prestigious Tibetan Buddhist institutions and clergy, the development of secular education, and economic difficulties, in particular following changes in land tenure. These four major areas of religious change are: (i) the relaxing of restrictions (based on caste or gender) governing access to certain forms of practice or initiation, (ii) new emphasis on paying proper attention to the meaning of the Sanskrit ritual texts or of the ritual procedures in themselves, (iii) the standardisation of ritual practice (among others through newly established teaching programs, about which interesting empirical data is provided in the appendix), and (iv) the deliberate development of certain forms of ritual practice in a conscious attempt to strengthen Newar Buddhism. The concluding remark on the contrast with Tibetan Buddhism, in which non-Tibetan practitioners "help perpetuate the tradition" (p. 234), perhaps would need to be nuanced; as von Rospatt rightly observes, contact with non-Tibetan followers has helped to attract substantial patronage, but non-Tibetan practitioners' religious lives remain to some extent sociologically segregated from those of common Tibetan practitioners, and the "tradition" they contribute to fostering has distinctively modern traits. This is only a minor quibble; the chapter is a highly interesting examination of the local religious 
context of what, ironically, has become one of the most iconic locations of contemporary Tibetan Buddhism - the Kathmandu valley.

11 In Chapter 10, "Ritual Efficacy or Spiritual Quest? Buddhism and Modernity in PostCommunist Mongolia", M.-D. Even presents a tripartite historical summary of the developments that have led to the present-day situation of Buddhism in Mongolia, from the early twentieth-century revolutionary period to the religious revival of the post-communist transition years and to the present. The author argues that the communist years have not destroyed Mongolian Buddhism and the Mongols' attachment to it, but that they have definitely weakened them. The examination of the contemporary situation focuses on the reformist, modernist forms of Buddhism that have been established in Mongolia in large part by transnational organisations such as the Foundation for the Preservation of the Mahāyāna Tradition, and which stand in stark contrast to the ritual-centred Buddhism practised by most Mongols. The title of the chapter highlights this tension, which Elverskog, drawing on studies of the forms Buddhism has taken in the West, has discussed under the designation "two Buddhisms". The discussion here focuses on the views of Westerners (e.g., p. 267 : "Western Buddhists appear to be dismayed by the practice of the locals"); it would have been interesting to procure a sense of how this tension is perceived by Mongols themselves, who, somewhat paradoxically, occupy a rather minor place in this last section of the chapter.

The last chapter, modestly entitled "Notes on Contemporary Ransom Rituals in Lhasa", by R. Barnett, amounts to more than a fourth of the entire volume. Here the author, a noted specialist of Tibetan politics and cinema, explores a well-known class of Tibetan rituals, lütor or lü (Tibetan glud-gtor, glud), or "ransom" rituals, from an original perspective : the presence in modern cityscapes, like that of Lhasa, of the ritual devices that are cast out at the close of the ritual, generally at crossroads. Directing more substantially our attention to rituals carried out in urban Tibetan contexts is highly overdue, and Barnett's initiative is welcome indeed; however, the author's remark about "the traditions of village ethnography, with their implied perception of the rural as backward and preserved" (p.316), appears as somewhat facile and out of touch with contemporary ethnography in rural contexts. It should also be noted that what is proposed here in exchange is not urban ethnography, but rather a composite whole made up of chance observations of ritual remains on Lhasa streets, photographic documentation, comments by informants and colleagues, and, most substantially, wideranging readings on lütor and similar rituals. Casting thus his net very widely enables the author to compose first a picture of the lütor rituals' possible origins and typical content. Adopting a more interpretive mode, the chapter addresses issues of representation (arguing that we have in the fashioning of effigies, thread-crosses and other implements a form of "art") and questions regarding interactions with invisible forces (maybe going somewhat too far when suggesting that this ritual necessitates an "understanding of the alien's psychology", p. 353). It finally offers a discussion on how the ritual remains at Lhasa's crossroads might be read, whether as a critique of modern culture, following Walter Benjamin and a suggestion by Ronald Schwartz (p. 350), or along the lines of an "ethnography of resistance", following for instance Scott (p. 352): here the author insists on "parallels" and the potential for "slippage" (pp. 352, 354, 355) between the more common private lütor exorcisms and collective, more political, similar ritual forms. Barnett's points are often relevant and stimulating, but in this last section his analysis occasionally manifests some slippage itself, shifting towards a more 
political agenda, like when we read that the "underlying thesis of the [lïtor ritual in general] is that subalterns can briefly assert themselves against foreign domination and intrusion (...). At times, with skill, the subject will engross the power-holders with that which they most urgently desire, usually professions of loyalty" (p. 354). Other quibbles could be voiced, such as where the text presents lü practices as carried out "by members of some Buddhist monasteries, or very often by practitioners and specialists in Bon communities" (p. 276, emphases added) - a contrast that reflects perhaps traditional Tibetan ideas about Bön more than a careful ethnographic assessment? Nevertheless, though this contribution is maybe somewhat long-winded, the elements brought together here constitute an at times very engaging fresco of this sector of Tibetan ritual culture.

Although one may close the book with a sense of regret for its lack of greater thematic focus and integration, one must acknowledge the generous gift of riches and stimulation that we find here. This volume is an important addition to any serious library collection on Tibetan religion.

\section{NOTES}

1. Sperling, E. 2012 Reincarnation and the Golden Urn in the 19th Century: The Recognition of the 8th Panchen Lama", in H. Blezer et al. (ed.), Studies on the History and Literature of Tibet and the Himalaya (Kathmandu, Vajra Publications), pp. 97-107. 